\title{
Growth and early laying performance of a broiler parent stock in an open-sided house under restricted feeding
}

\author{
MR Rahman ${ }^{1}$, SD Chowdhury* ${ }^{2}$, ME Hossain ${ }^{2}$, M Ahammed $^{2}$ \\ ${ }^{1}$ School of Agriculture and Rural Development, Bangladesh Open University, Gazipur; ${ }^{2}$ Department of Poultry \\ Science, Bangladesh Agricultural University, Mymensingh 2202, Bangladesh
}

\begin{abstract}
An experiment was carried out with SHAVER Starbro broiler parent stock from one day old to the point of peak production to investigate the growth, early laying performance and their adaptability during brooding, growing and early laying periods. The experimental period was divided into five phases, phase I $\left(0-2^{\text {nd }}\right.$ week $)$, phase II $\left(3^{\text {rd }}-8^{\text {th }}\right.$ week $)$, phase III $\left(9^{\text {th }}-22^{\text {nd }}\right.$ week $)$, phase IV $\left(23^{\text {rd }}-\right.$ sexual maturity), phase $\mathrm{V}$ (sexual maturity to peak production). The experiment was carried out in an open sided house and management practices of birds were close to the recommendation of the broiler breeder. It may be concluded that it is possible to achieve standard body weight of SHAVER Starbro broiler parent stock under Bangladesh condition even sometimes with lower amounts of feed allocations as specified by breeder. The birds reach sexual maturity at $31^{\text {st }}$ week, later than the breeder's standard $\left(23^{\text {rd }}\right.$ week) and the persistency in peak production is shorter but egg weight ranges from $53 \mathrm{~g}$ to $60 \mathrm{~g}$, suitable for hatching. Mycoplasmosis appears to be major health problem, affecting performance. Use of sand is not suitable as a litter material for the management, as the birds consume a lot of sand under restricted feeding program. It may be suggested that SHAVER Starbro broiler parent stock could be reared under Bangladesh condition for the production of hatching eggs.
\end{abstract}

Key words: Broiler parent stock, Feed restriction, Productive performance, Adaptability

Bangladesh Animal Husbandry Association. All rights reserved.

Bang. J. Anim. Sci. 2015. 44 (1): 40-45

\section{Introduction}

The performance of commercial broiler chicks depends mostly on the quality of chicks obtained from parent stocks. Because, the chicks inherit superior genes from parents and express better genetic potentiality under condition of appropriate environment. Most of the world's leading poultry breeding companies are located in temperate region, while their products are marketed all over the world in varied conditions of climate, husbandry, feeds and feeding practices. For this reason, the productive performance of exotic strains usually varies from country to country.

Broiler breeder hens grow more efficiently and leaner than ever before due to positive results from broiler genetic selection strategies. Body weight during growing phase is the key factor of successful broiler parent stock production that influences age at sexual maturity and breeder performance. Quantitative feed restriction is used to limit excessive weight gain, maximize egg production and fertility (Renema et al. 2007) whereas ad libitum feeding results in poor egg production, low hatchability and high mortality (Hocking et al. 2005). The management technologies of broiler parent stock production are to be improved regularly. Das et al. (2008) reported that in Bangladesh the number of broiler parent stock was only 750 thousands in 2000 but at the end of 2005 it increased to 2292 thousands. Although a good number of parent stocks of foreign origin are being imported and reared under Bangladesh conditions, data on growth performance particularly achieved body weight as against target body weight and productive performance when reared in an open sided house are lacking in the literatures. Therefore, the present study was undertaken to investigate the growth performance (body weight, body weight gain, feed intake, survivability) and productive performance (age at first lay, egg production, egg weight) of Starbro broiler parent stocks resulting from quantitative feed restriction reared in an open sided house and to compare these data with the standard to 
assess their adaptability under Bangladesh condition.

\section{Materials and Methods}

This investigation was carried out in an open sided poultry house and the experimental period was divided into 5 phases. The layout of the experiment is shown in Table 1. The house was prepared before the arrival of chicks. Cleaning and disinfection of the shed and poultryequipment were done before the placement of chicks. The experiment was conducted by providing identical care, management and environmental conditions for chicks in each phase like feeding, watering, ventilation, lighting, vaccination and prevention of diseases. Fresh sawdust was used as a litter material and it was spread on the floor at a depth of $1.5 \mathrm{~cm}$ and gradually increased up to $3 \mathrm{~cm}$ at the end of $7^{\text {th }}$ week. To prevent litter picking by the chicks, newspaper was spread over the litter material for the first 5 days. At eighth week of age, birds were placed in a new pen and reared on fresh sand as a litter material at a depth of $5 \mathrm{~cm}$ till the end of experiment. Sometimes, bleaching powder was spread on the litter materials to kill pathogenic microorganism. Litter materials were stirred frequently to prevent dampness and cake formation. The birds were brooded for the first two weeks of age, using 100-watt electric bulbs, as a source of heat. Brooder temperature was adjusted according to chick's behavior and need.

Twenty-four hours light was provided to the birds up to $2^{\text {nd }}$ week of age. From $3^{\text {rd }}$ week, lighting hours were gradually decreased daily and then maintained 12 hours up to $19^{\text {th }}$ weeks of age. During laying period, 15 hours lighting was maintained for the remaining experimental period. Lighting requirement was fulfilled by adjusting additional artificial light with the natural day length. For the preparation of the future feed restriction program, the chicks were fed ad libitum from day old to 2 weeks of age. From $3^{\text {rd }}$ to $8^{\text {th }}$ weeks of age, feed was allocated as per breeder's instructions twice a day and from $9^{\text {th }}$ to $36^{\text {th }}$ weeks of age once a day. Feed allowance was dependent on body weight. When the birds were above the standard weight, then feed allocation was kept as before. When the body weight was on standard, the breeder's recommendation was followed. If the body weight was below standard, feed supply was increased by $1 \mathrm{~g}$ for each $50 \mathrm{~g}$ under weight. Amount of feed supplied in the previous week was never reduced in the next week. During the growing period, uniformity was calculated and under weight and overweight birds were maintained separately by following feeding schedule mentioned above in order to bring their body weights within $\pm 10 \%$ of standard weight. In the production stage, feed was supplied according to the rate of production. Fresh, clean and cool water was given ad libitum for the first 2 weeks and then according to the breeder's recommendation. At $13^{\text {th }}$ week of age debeaking was done. Birds were vaccinated against Infectious Bronchitis and Newcastle disease, Gumboro, Fowl pox, Fowl cholera by Ma5 Clone30, Gumboro 228E, Fowl pox, Fowl cholera vaccine respectively by following manufacturer's instructions. One wooden nests of $45 \mathrm{~cm} \times 45 \mathrm{~cm} \times$ $45 \mathrm{~cm}$ (height $x$ width $x$ length) was supplied for each 4 females and placed in a corner of the each pen to facilitate the laying during laying period.

Table 1. Layout of the experiment

\begin{tabular}{|c|c|c|c|c|c|c|}
\hline \multirow[t]{2}{*}{ Phases } & \multirow{2}{*}{ Age (week) } & \multicolumn{2}{|c|}{ No. of group } & \multicolumn{2}{|c|}{$\begin{array}{l}\text { No. of birds/ } \\
\text { replication }\end{array}$} & \multirow{2}{*}{ - Comments } \\
\hline & & Male & Female & Male & Female & \\
\hline I & 0 to $2^{\text {nd }}$ & & 3 & & 67 & Mixed sex \\
\hline II & $3^{\text {rd }}$ to $8^{\text {th }}$ & 3 & 3 & 11 & 55 & Separate sex \\
\hline III & $9^{\text {th }}$ to $22^{\text {nd }}$ & 3 & 6 & 11 & 23 & Separate sex \\
\hline IV & $23^{\text {rd }}$ to SM & 3 & 10 & 2 & 12 & Separate sex \\
\hline V & SMPP & & 5 & 2 & 12 & Mixed sex \\
\hline
\end{tabular}

SM, sexual maturity; SMPP, SM to peak production

Body weight, feed intake, sexual maturity, egg production, mortality were recorded and body weight gain, feed consumption, livability, henhoused egg production were obtained by calculations. Data were analyzed statistically by using SPSS version 8.0 statistical computer package programs.

\section{Results and Discussions}

In phase I and II, the day old body weight of Starbro broiler parent stock was $37 \mathrm{~g}$, similar (36g) to Kasila parent chicks (Hossain et al. 


\section{Performance of a broiler parent stock}

2005). From $3^{\text {rd }}$ week and onwards, when achieved body weight was compared with the standard growth curve, it was observed that growth curve followed the standard curve very closely except at $4^{\text {th }}, 7^{\text {th }}$ and $8^{\text {th }}$ weeks of age. In these weeks, the achieved body weight was slightly higher (42, 113, $186 \mathrm{~g} /$ bird respectively) than the standards (Figure 1) and body weights at all other ages were within the ranges of $\pm 10 \%$ of the standard body weight. The results agreed with Hossain et al. (2005), and Chowdhury et al. (2010) who found that the achieved body weight followed the standard curve very closely for some available broiler parent chicks. The feed consumption of birds was slightly higher (4 $\mathrm{g} / \mathrm{bird} /$ day) at $6^{\text {th }}$ week of age and slightly lower ( $5 \mathrm{~g} / \mathrm{bird} /$ day) at both $5^{\text {th }}$ and $8^{\text {th }}$ week of age than the standard feed consumption data of this strain. However, the amount of feed consumed during $2^{\text {nd }}, 3^{\text {rd }}, 4^{\text {th }}$ and $7^{\text {th }}$ week of age was close to the standards. Body weight gain at $2^{\text {nd }}$ phase was significantly higher than the standards due to ad libitum feeding. This result was not in agreement with the findings of Hossain et al. (2005) and Chowdhury et al. (2010) who also supplied ad libitum feed during early two weeks of brooding period.

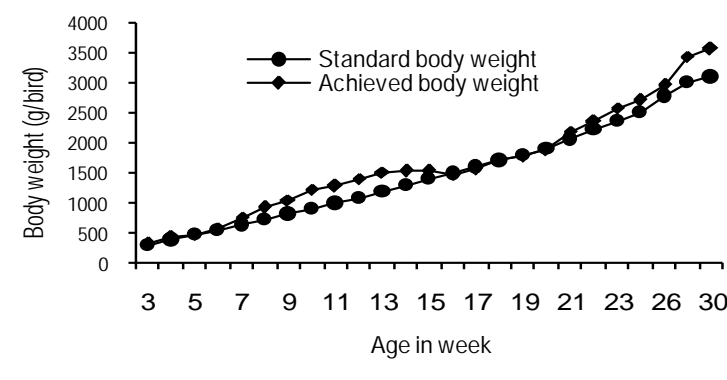

Figure 1. Female growth curve (standard vs achieved)

During phase III, the birds showed an upward trend in the body weight gain than the standards during $9^{\text {th }}$ to $15^{\text {th }}$ weeks of age (Figure 1 ). The achieved body weight of female chicks at $9^{\text {th }}$ to $15^{\text {th }}$ weeks of age was higher than the standard average body weight ranges. Surprisingly, the birds consumed lower amounts of feed ( $44 \mathrm{~g} / \mathrm{bird} /$ day) in this period than the recommendation. From $16^{\text {th }}$ to $20^{\text {th }}$ weeks of age, the achieved body weights were close to the standards. But in those weeks, birds consumed lower amounts of feed $(44,55,58,68,77$ $\mathrm{g} /$ day/bird respectively) than that of the standards. Jong et al. (2002) found that restricted birds show hyperactivity, stereotyped pacing before feeding time and stereotyped drinking and pecking at non-food object after feeding. In this study, the restricted birds also consumed litter materials (sand) during the feed restriction period.

Fattori (1991) found a growth curve that was parallel with standard curve resulting from below standard feed allocation (-8\%, $-16 \%$ and $-24 \%)$. The result of the present study coincided with Fattori (1991). A significant $(p<0.01)$ difference between standard and achieved body weight at $22^{\text {nd }}$ week of age were found. This result was not in agreement with the findings of Pearson and Herron (1981) who found no significant difference in body weight at $22^{\text {nd }}$ week of age. During $3^{\text {rd }}$ phase, the difference between standard and achieved body weight gain was non-significant. The result of present study coincided with the findings of Chopra and Agarwal (1995), who reported reduced body weight gain during $8^{\text {th }}$ to $22^{\text {nd }}$ weeks of age.

Body weight was taken fortnightly and it showed an upward trend during phase IV. Body weight at $24^{\text {th }}, 26^{\text {th }}, 28^{\text {th }}$, and $30^{\text {th }}$ weeks, of age was higher (199g, 185g, 437g, 455g respectively) than the standards. The body weight at $24^{\text {th }}$ and $26^{\text {th }}$ weeks was within the range of $\pm 10 \%$ and at $28^{\text {th }}$ and $30^{\text {th }}$ weeks exceeded the range of $\pm 10 \%$ of the standard average body weight. According to the standard, the birds were due for sexual maturity at $23^{\text {rd }}$ week, but in this study it was delayed by 8 weeks. After sexual maturity, feed allowance was depended upon percent of egg production. In this phase, feed was given not more than the standard amount allocated for $22^{\text {nd }}$ week of age. Significant difference $(p<0.01)$ was observed among the standard and achieved body weight at sexual maturity. In this phase, the birds suffered from chronic Mycoplasmosis, which might be the cause of late maturity. Body weight at sexual maturity might have increased due to late maturation. This result coincided with the Hurwitz and Plavnic (1989), who concluded that body weight at onset of production significantly increased as sexual maturity was delayed. 
In phase I and II, the achieved body weight was lower $(19 \mathrm{~g} / \mathrm{bird})$ than the standard but it was within the standard average body weight range of $\pm 10 \%$ at the end of $2^{\text {nd }}$ week. This condition was brought under control by supplying more feed ( $2 \mathrm{~g} / \mathrm{bird} /$ day) than the standard. The achieved growth curve showed little higher trend from the standard growth curve, in spite of lower feed allocation. This result coincided with Fattori et al. (1991) who reported that in case of broiler parent it was possible to obtain target body weight by supplying lower amounts of feed than the standard allocation. The results of a recent study with some other strains also supported this view (Chowdhury et al. 2010).

Achieved body weight during phase $1 \mathrm{II}$ is shown in Table 2. At $10^{\text {th }}$ week of age, the achieved body weight was higher (135g/bird) than the standard. Although the achieved body weight at $8^{\text {th }}, 9^{\text {th }}, 11^{\text {th }}$ and $12^{\text {th }}$ week was slightly higher (54, 82, 34 and $13 \mathrm{~g} /$ bird respectively) than the standard body weight, all the weights were within the range of $\pm 10 \%$ of standard average body weight (Figure 2). Feed consumed by the birds was very much lower at $8^{\text {th }}$ to $20^{\text {th }}$ weeks respectively than the recommended allowances. The feed consumption at $21^{\text {st }}$ and $22^{\text {nd }}$ weeks was very close to the standard. The difference in body weight gains during $9^{\text {th }}$ to $22^{\text {nh }}$ weeks were notsignificant ( $p>0.05)$ as compared to the standard body weight gain. The result of this study coincided with the findings of Chopra and Agarwal (1995) who reported reduced body weight gain during $8^{\text {th }}$ to $22^{\text {nd }}$ weeks of age.

The achieved growth curve showed an upward trend than the standard growth curve during phase IV. During $24^{\text {th }}$ to $30^{\text {th }}$ weeks, body weight was higher (116, 237, 739, 943 g/bird respectively). The body weights at $24^{\text {th }}$ and $26^{\text {th }}$ weeks were within the range of standard average weight but body weights at $28^{\text {th }}$ and $30^{\text {th }}$ week were higher. In this period, the birds consumed required amounts $(131.5 \mathrm{~g})$ of feed daily. During this phase, the difference between standard and achieved body weight gain was significant $(p<0.01)$.
Table 2. Body weight of Starbro parent stock at different phases

\begin{tabular}{|c|c|c|c|c|}
\hline Phase & Sex & Age (week) & $\begin{array}{c}\text { Achieved } \\
\text { weight } \\
\text { (g/bird) }\end{array}$ & $\begin{array}{c}\text { Standard } \\
\text { weight } \\
\text { (g/bird) }\end{array}$ \\
\hline I & Mixed & Day old & 37 & $\overline{N A}$ \\
\hline \multirow{2}{*}{ ॥ } & \multirow{2}{*}{ Male } & $2^{\text {nd }}$ (initial) & 180 & 200 \\
\hline & & $8^{\text {th }}$ (final) & $1041^{a}$ & $960^{b}$ \\
\hline \multirow{2}{*}{ II } & \multirow{2}{*}{ Female } & $2^{\text {nd }}$ (initial) & 187 & 200 \\
\hline & & $8^{\text {th }}$ (final) & $907 \mathrm{a}$ & $715^{b}$ \\
\hline \multirow{2}{*}{ III } & \multirow{2}{*}{ Male } & $9^{\text {th }}$ (initial) & $1041^{a}$ & $960^{b}$ \\
\hline & & $22^{\text {nd }}$ (final) & 3246 & 3240 \\
\hline \multirow{2}{*}{ III } & \multirow{2}{*}{ Female } & $9^{\text {th }}$ (initial) & $907^{a}$ & $715^{b}$ \\
\hline & & $22^{\text {nd }}$ (final) & $2333^{a}$ & $2200^{b}$ \\
\hline \multirow{2}{*}{ IV } & \multirow{2}{*}{ Male } & $23^{\text {rd }}$ (initial) & 3246 & 3240 \\
\hline & & At sexual maturity (final) & $4893^{a}$ & $3950^{b}$ \\
\hline \multirow{2}{*}{ IV } & \multirow{2}{*}{ Female } & $23^{\text {rd }}$ (initial) & $2333^{a}$ & $2200^{b}$ \\
\hline & & At sexual maturity (final) & $3548^{a}$ & $3090^{\mathrm{b}}$ \\
\hline
\end{tabular}

$\mathrm{Na}$, not available; Means with different superscript in the same column differed significantly $(p<0.01)$

Similar observation was found by Hurtwitz and Plavnic (1989) who reported that body weight at onset of production significantly increased because of delay in sexual maturity. The birds came to maturity at 217 days old, which was much later than the breeder's standard (168 days). Kumar et al. (1998) showed that the broiler female came to maturity at the age of 146 days. In this study, the broiler breeder came into lay slightly later than usual time. This was probably due to Mycoplasma infection in the flock in epidemic form during pre-breeding period.

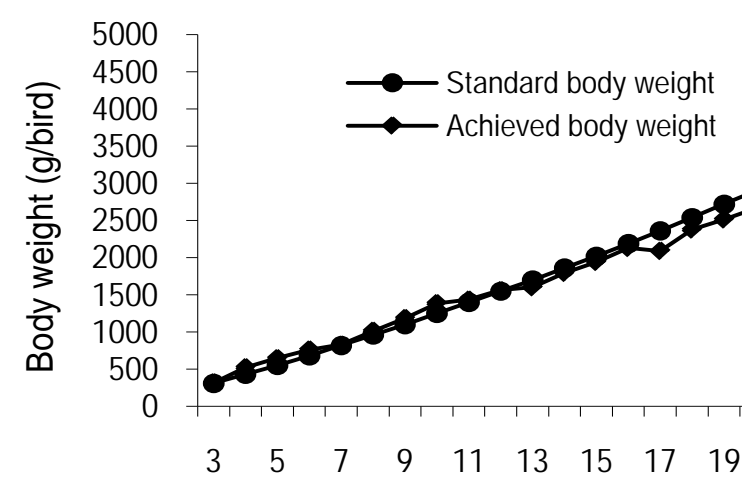


Egg production during early laying period of the experiment is presented in Table 4. The average egg production was $38.17 \%$, which was very low. This was because the birds suffered from Mycoplasma infection and were over weighed at the age of sexual maturity. Reduced egg production due to Mycoplasmosa infection was previously reported by Borges et al. (1999) in commercial laying hens. Robinson (1996) reported that body weight was associated with significant reduction in hatching eggs. Age at peak production was 252 days, which was much later than that indicated in the breeder's manual (203-217 days). Persistency of laying peak was 7 days, which was also shorter than the standard (14 days). At the peak production, hen-day egg production was $63.08 \%$, which was also lower than the standard (84\%) (Table 4$)$. The average egg weight during the experimental period was 57.68g. Weekly egg weight during the experiment is shown in Table 4. The result showed an usual trend that egg weight increased with the advancement of age. Gous et al. (2000) found that egg weight increased with an increase in bird's age. Luykx (1994) observed larger egg from older hens. Robbin et al. (1988) concluded that egg weight was significantly affected by hen's age. The percent broken egg obtained during the experimental period was 9.02. The percentage of broken egg was highest at $31^{\text {st }}$ weeks of age but lowest at $32^{\text {nd }}$ weeks of age. The number of soft-shelled eggs laid during the experimental period was $12.11 \%$. At $31^{\text {st }}$ week no soft-shelled egg was found. The number of soft-shelled egg decreased with the advancement of age.

Table 3. Body weight gain of Starbro broiler parent stock at different phases

\begin{tabular}{lllcc}
\hline Phase & Age (week) & Sex & $\begin{array}{c}\text { Achieved weight } \\
\text { gain (g/bird) }\end{array}$ & $\begin{array}{c}\text { Standard weight } \\
\text { gain (g/bird) }\end{array}$ \\
\hline I & $1-2$ & Mixed & 147 & NA \\
\hline II & \multirow{2}{*}{$3-8$} & Male & 831 & 760 \\
\cline { 3 - 5 } & Female & $720^{\mathrm{a}}$ & $515^{\mathrm{b}}$ \\
\hline III & \multirow{2}{*}{$9-22$} & Male & 2224 & 2280 \\
\cline { 3 - 5 } & & Female & 1424 & 1485 \\
\hline IV & \multirow{2}{*}{$23-S S$} & Male & $1667^{\mathrm{a}}$ & $710^{\mathrm{b}}$ \\
\cline { 3 - 5 } & & Female & $1224^{\mathrm{a}}$ & $890^{\mathrm{b}}$ \\
\hline
\end{tabular}

$\mathrm{Na}$, not available; Means with different superscript in the same column differed significantly $(p<0.01)$; SS, sexual maturity
Table 4. Egg production traits during the experimental period

\begin{tabular}{ccccc}
\hline $\begin{array}{c}\text { Age } \\
\text { (week) }\end{array}$ & $\begin{array}{c}\text { *Hen day egg } \\
\text { production (\%) }\end{array}$ & $\begin{array}{c}\text { Soft-shelled } \\
\text { egg (\%) }\end{array}$ & $\begin{array}{c}\text { Broken } \\
\text { egg (\%) }\end{array}$ & $\begin{array}{c}\text { Average egg } \\
\text { weight (g) }\end{array}$ \\
\hline 31 & 5.83 & - & 14.29 & 52.50 \\
32 & 10.0 & 33.33 & 4.76 & 55.32 \\
33 & 23.80 & 20.00 & 7.00 & 54.67 \\
34 & 39.25 & 12.12 & 10.30 & 55.33 \\
35 & 54.73 & 10.43 & 8.26 & 58.58 \\
36 & 63.08 & 7.55 & 9.43 & 59.71 \\
\hline
\end{tabular}

*Number of female breeders was 60

Survivability of birds during different phases of experiment is presented in Table 5. During the whole experiment period survivability in case of male was $90.11 \%$ and for female it was $94.88 \%$. Mortality was very low during the early period of growth (0-2 weeks). Before sexual maturity, especially during 29 and 30 weeks of age, the mortality was very high due to mycoplasmosis and severity was higher in case of male than the female.

Table 5. Survivability of birds during experimental period

\begin{tabular}{cccc}
\hline Phase & Age (week) & Male (\%) & Female (\%) \\
\hline I & $0-2$ & 99.5 & 100.0 \\
II & $3-8$ & 100.0 & 97.0 \\
III & $9-22$ & 88.6 & 99.9 \\
*IV & 23-31 (at sexual maturity) & 62.5 & 77.5 \\
V & 31-Peak production & 100.0 & 100.0 \\
\hline
\end{tabular}

*Mycoplasmosis affected production in phase IV

\section{Conclusions}

It may be concluded from this study that it is possible to achieve standard body weight of SHAVER Starbro broiler parent stock in an opensided house in Bangladesh even sometimes with lower amounts of feed allocations. The birds may come into sexual maturity later than the standard as suggested by the breeder and persistency in peak production may be shorter but egg weight may range from 53 to $60 \mathrm{~g}$ which is suitable for hatching. Mycoplasmosis appears to be the major health problem, which affects growth and subsequent performance of parent stock. Use of sand is not suitable as litter material for the management of parent stock since under restricted feeding program, the birds may 
consume a lot of sand. It may be suggested that SHAVER Starbro broiler parent stock could be reared successfully under Bangladesh condition for the production of hatching eggs but special care would be required for the prevention of myco-plasmosis.

\section{References}

Borges VF, Godoy A, Valle A (1999). Economic losses in egg production caused by Mycoplasma infection in Aragua State. Venezuela Zootecnia Tropical, 17: 261276.

Chopra SK, Agarwal CK (1995). Effects of quantitative feed restriction on the performance of growing turkeys. Indian J ournal of Poultry Science, 30: 241-243.

Chowdhury SD, Das C, Pramanik MAH, Roy BC, Roy CR, Saha SK (2010). Broiler Parent Stock Production in Bangladesh: Growth Performance and Uniformity in Open-Sided Houses under Restricted Feeding. Indian J ournal of Animal Nutrition, 27: 422-431.

Das SC, Chowdhury SD, Khatun MA, Nishibori M, Isobe N, Yoshimura $Y$ (2008). Poultry production profile and expected future projection in Bangladesh. World's Poultry Science Journal, 64: 99-117.

Fattori TR, Wilson HR, Harms RH, Miles RD (1991). Response of broiler breeder females to feed restriction below recommended levels 1 . Growth and reproductive performance. Poultry Science, 70: 26-36.

Gous RM, Bradford GD, Thonston SA, Morris, TR (2000). Effect of age of release from light or food restriction on age at sexual maturity and egg production of laying pullets. British Poultry Science, 41: 263271.

Hocking, PM, Jones, EKM, Picard M (2005). Assessing the welfare consequences of providing litter for feed restricted broiler breeders. British Poultry Science, 46: 545552.

Hossain ME, Chowdhury SD, Ahammed M. Pramanik MAH, Rahman MR (2005).
Growth performance of Kasila broiler parent stock reared on quantitative feed restriction under Bangladesh condition. International J ournal of Poultry Science, 4: 153-158.

Hurwitz S, Plavnik I (1989). Severe feed restriction in pullet during the early growing period: Performance and relationship among age, body weight and egg weight at the onset of production. Poultry Science, 68: 914-924.

Jong de IC, Voorst van S, Ehihardt DA, Blokhuis HJ (2002). Effects of restricted feeding on physiological stress parameters in growing broiler breeder. British Poultry Science, 43: 157-168.

Kumar S, Singh RP, Kumar J, Kanaujia AS (1998). Optimization of body weight and age in relation to egg production in broiler dam line. Canadian Journal of Animal Science, 78: 65-67.

Luykx R (1994). Effect of genotype, age and storage on egg characteristics and hatchability in broiler breeder. $9^{\text {th }}$ European Poultry Conference, Glasgow.

Pearson RA, Herron KM (1981). Effects of energy and protein allowances during lay on the reproductive performance of broiler breeder hens. British Poultry Science, 22: 227-239.

Renema RA, Rusted ME, Robinson EE (2007). Implications of changes to commercial broiler and broiler breeder body weight targets over the past 30 years. World's Poultry Science J ournal, 63: 457-472.

Robbin KR, Mcghee GC, Robertson KD (1988). Effect of ad libitum vs. restricted feeding on body composition and egg production of broiler breeder. Poultry Science, 67: 219225.

Robinson FE (1996). What is the relationship between egg production and hatchability? World Poultry Misset, 12: 2-4. 